\title{
Cerebellar EBV-associated diffuse large B cell lymphoma following angioimmunoblastic $T$ cell lymphoma
}

\author{
Yi Zhou • Marc K. Rosenblum • Ahmet Dogan • \\ Achim A. Jungbluth • April Chiu
}

Received: 28 October 2014 / Accepted: 4 March 2015 / Published online: 18 March 2015

(C) Springer-Verlag Berlin Heidelberg 2015

\begin{abstract}
Epstein-Barr virus (EBV)-associated B cell lymphoproliferative disorders may be seen in patients with angioimmunoblastic T cell lymphoma (AITL). Although both nodal and extranodal sites of involvement have been described, central nervous system involvement by B cell lymphoma following AITL has not previously been documented. We report a first example of such unusual presentation, in which an 80-year-old man developed diffuse large B cell lymphoma (DLBCL) in the cerebellum 4 months after the initial diagnosis of AITL. EBV-encoded RNAs were detected in the DLBCL, suggesting that EBV played a pivotal role in the pathogenesis of high-grade histologic progression of AITL. The patient survived less than 9 months after his initial diagnosis of AITL. We believe that this case expands the spectrum of extranodal manifestation of EBV-positive B cell lymphoma associated with AITL and illustrates the importance of recognition of this association when encountering unusual central nervous system lesions in patients with known AITL.
\end{abstract}

Keywords Angioimmunoblastic T cell lymphoma . Diffuse large B cell lymphoma · Central nervous system

\section{Introduction}

Angioimmunoblastic T cell lymphoma (AITL) is a rare but aggressive subtype of peripheral T cell lymphoma (PTCL), accounting for $15-20 \%$ of PTCL and $1-2 \%$ of all non-

\section{Y. Zhou $(\bowtie)$}

Department of Pathology, Loyola University Medical Center, Rm 2222, Building 110, 2160 S 1st Ave, Maywood, IL 60153, USA e-mail: yi.zhou@lumc.edu

M. K. Rosenblum • A. Dogan · A. A. Jungbluth · A. Chiu Department of Pathology, Memorial Sloan-Kettering Cancer Center, New York, NY 10065, USA
Hodgkin lymphoma cases [1]. AITL was previously considered an atypical reactive process termed angioimmunoblastic lymphadenopathy with dysproteinemia (AILD), with propensity of progression to frank T cell lymphoma [2, 3]. However, subsequent genetic studies demonstrated presence of monoclonal $\mathrm{T}$ cell receptor gene rearrangements as well as clonal cytogenetic abnormalities in vast majority of the cases, supporting the neoplastic nature of the proliferation from the onset $[4,5]$. Consequently, AITL is recognized as a distinct clinicopathologic entity in the current WHO classification [6].

Patients with AITL tend to be middle-aged or elderly and present with advanced stage disease with systemic symptoms, including autoimmune phenomena such as circulating immune complex, cold agglutinins, hemolytic anemia, and presence of rheumatoid factor and/or anti-smooth muscle antibodies. Polyclonal hypergammaglobulinemia is present in approximately $50 \%$ of patients [6]. Most cases show an aggressive clinical course with a median survival of less than 3 years $[7,8]$.

Histologically, AITL primarily manifests as nodal disease characterized by architectural effacement by a polymorphous proliferation of small- to intermediate-sized $\mathrm{T}$ lymphocytes with clear cytoplasm and minimal cytologic atypia, in a background of arborizing high endothelial venules and proliferation of follicular dendritic cell meshworks. The neoplastic T cells are positive for $\mathrm{CD} 4$, although they may be masked by numerous reactive $\mathrm{CD} 8^{+} \mathrm{T}$ cells in the background. In addition, the neoplastic $\mathrm{T}$ cells typically express two or more follicular helper $\mathrm{T}$ cell $\left(\mathrm{T}_{\mathrm{FH}}\right)$ markers: CD10 [9], PD-1 [10], and CXCL-13[11]. In up to $97 \%$ of the cases, there is also an expansion of B immunoblasts that are infected by EpsteinBarr virus (EBV) [12]. The nearly constant association of AITL with EBV led to suggestion of a possible etiologic role for the virus, possibly through antigen drive [13]. Interestingly, even though the neoplastic T cells are EBV-negative, highgrade histologic progression, when occurring in rare occasions, is usually to a B cell lymphoma that is usually EBV- 
positive [14]. Reported sites of involvement include lymph node [14-17], skin [18-20], bone marrow [14, 15], small intestine [21], and lung [22]. To our knowledge, central nervous system (CNS) involvement by an EBV-positive B cell lymphoma following a diagnosis of AITL has not been previously documented in literature. We hereby report a case of EBVassociated diffuse large B cell lymphoma (DLBCL) involving the cerebellum of an elderly man 4 months after his initial clinical presentation of nodal AITL.

\section{Case report}

An 80-year-old man presented in July 2011 with joint swelling that was intermittently treated with steroids over a 4-month period. He then noted new cervical lymphadenopathy measuring up to $1 \mathrm{~cm}$ in size, associated with cough and fatigue. He received antibiotic treatment that was complicated by an allergic reaction, including leg rash/edema and chills, and ultimately required hospitalization. A chest X-ray in January 2012 showed small bilateral pleural effusions as well as hilar prominence. A CT scan showed mediastinal and bilateral hilar and axillary lymphadenopathy that measured up to $1.9 \mathrm{~cm}$ in size. A complete blood analysis revealed WBC $4.5 \mathrm{~K} / \mathrm{uL}$, hemoglobin $8.7 \mathrm{~g} / \mathrm{dL}$, and platelet $419 \mathrm{~K} / \mathrm{uL}$; differential: neutrophils $93.8 \%$, lymphocytes $4.4 \%$, and monocytes $1.3 \%$. Serology for human immunodeficiency virus, human $\mathrm{T}$ cell leukemia virus type 1 , hepatitis $\mathrm{B}$, and hepatitis $\mathrm{C}$ was negative.

The patient underwent fine needle aspiration biopsy of the cervical node in March 2012 at an outside hospital. He was initially diagnosed with sarcoidosis and started on low-dose prednisone $(15 \mathrm{mg} /$ day $)$ with initial mild symptomatic improvement. However, his symptoms, including leg swelling, lymphadenopathy, and fatigue, recurred and worsened over the next month, particularly when his prednisone dosage was decreased to $7.5 \mathrm{mg} /$ day. He then developed worsening anemia with hemoglobin level as low as $7.0 \mathrm{~g} / \mathrm{dL}$. A CT scan revealed splenomegaly $(16 \mathrm{~cm})$ and widespread lymphadenopathy, including bilateral hilar, mesenteric (up to $1.4 \mathrm{~cm}$ ), retroperitoneal (up to $2.5 \mathrm{~cm}$ ), bilateral common iliac, internal iliac, obturator, external iliac, and inguinal regions (up to $3.2 \mathrm{~cm}$ ). He continued on low-dose prednisone and underwent a bone marrow biopsy that showed unremarkable findings. He then underwent an excisional cervical lymph node biopsy, which led to the diagnosis of AITL. He began treatment of prednisone $50 \mathrm{mg} /$ day and noticed rapid regression of his lymphadenopathy. A PET scan in April 2012 demonstrated diminished lymphadenopathy (less than $1 \mathrm{~cm}$ ). However, his hemoglobin level remained low $(7.4 \mathrm{~g} / \mathrm{dL})$, for which the patient received two packed red blood cell units.

In July 2012, after being taken off prednisone for 1 month, the patient again started to develop mild joint swelling and pain, as well as mild palpable lymphadenopathy on examination. PET-CT scan and MRI were performed to assess lymphoma progression. A new $2.7-\mathrm{cm}$ rim-enhancing and centrally necrotic lesion was found in the posterior-inferior aspect of the left cerebellum (Fig. 1). A left cerebellum biopsy was performed, which demonstrated involvement by EBVpositive DLBCL. The patient received one cycle of rituximab, followed by one cycle of rituximab, methotrexate, and vincristine. Due to adverse reactions to methotrexate and vincristine, he subsequently received one more cycle of rituximab alone. The patient's clinical course was complicated by biopsyrelated subdural hematoma, burr hole drainage-related small intraparenchymal hemorrhage, left lower extremity deep vein thrombosis, urinary tract infection (Klebsiella), upper respiratory infection (Parainfluenza type 1), and HHV6 infection. He eventually died 8 months after the initial diagnosis of nodal AITL and 4 months after the diagnosis of cerebellar DLBCL.

Institutional review of the cervical lymph node biopsy from March 2012 revealed a lymph node with effaced architecture due to paracortical expansion by an atypical lymphoid proliferation composed of small to medium lymphocytes with mature chromatin and scant to moderate amount of cytoplasm, admixed with scattered larger cells with prominent nucleoli (Fig. 2a, b). There is also a proliferation of high endothelial venules. Immunohistochemical studies performed at our institution demonstrated that the atypical lymphoid proliferation is composed of predominantly $\mathrm{T}$ cells ranging from small to intermediate to occasionally large in size. The atypical $\mathrm{T}$ cells are positive for CD2, CD7, CXCL13 (Fig. 2c), and PD-1 (Fig. 2d) with reduced $\mathrm{CD} 3$ and $\mathrm{CD} 5$ expression, while negative for CD10, BCL-6, CD25, and CD56. The T cells, particularly the larger atypical forms, are predominantly CD4positive, although a moderate number of CD8-positive small

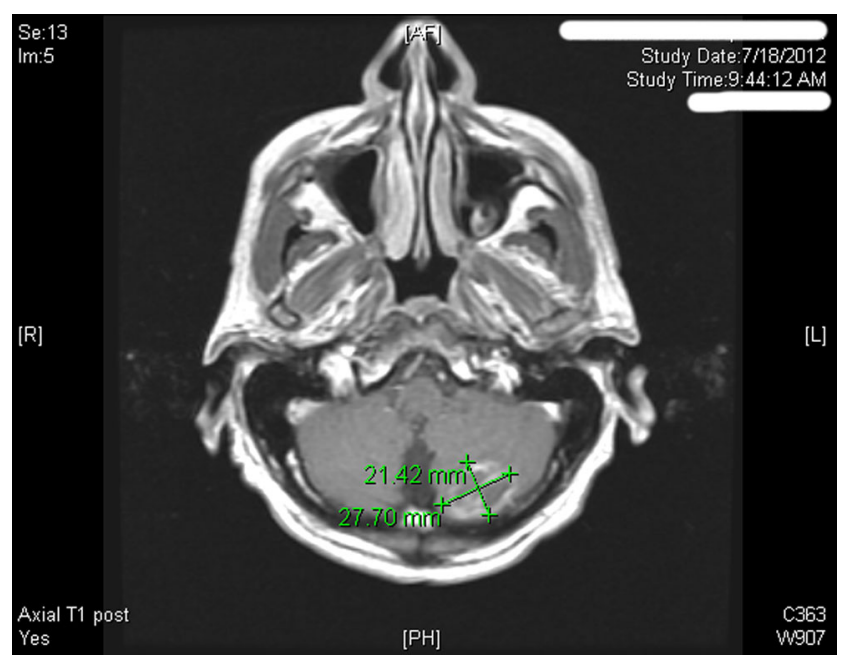

Fig. 1 MRI of the brain. A $2.7 \times 2.1 \mathrm{~cm}$ ring-enhancing mass lesion is detected within the left posterior cerebellum. There is mild edema around the lesion as well as hemorrhage or mineralization within the enhancing rim 
Fig. 2 Angioimmunoblastic T cell lymphoma in cervical lymph node biopsy. a The nodal architecture is effaced due to paracortical expansion by an atypical lymphoid proliferation $(\mathrm{H} \& \mathrm{E}, \times 40)$. b The atypical lymphoid proliferation is composed of small to medium lymphocytes with mature chromatin and scant to moderate amount of cytoplasm, admixed with scattered larger cells with prominent nucleoli. There is also a proliferation of high endothelial venules $(\mathrm{H} \& \mathrm{E}, \times 400)$. The atypical lymphoid proliferation is composed of numerous T cells expressing CXCL13 (c; $\times 400)$ and PD-1 (d; $\times 400)$. e CD20 $(\times 400)$ highlights scattered large cells (B immunoblasts). f In situ hybridization for Epstein-Barr virus-encoded RNA/EBER $(\times 400)$ shows that the B immunoblasts are infected by EBV
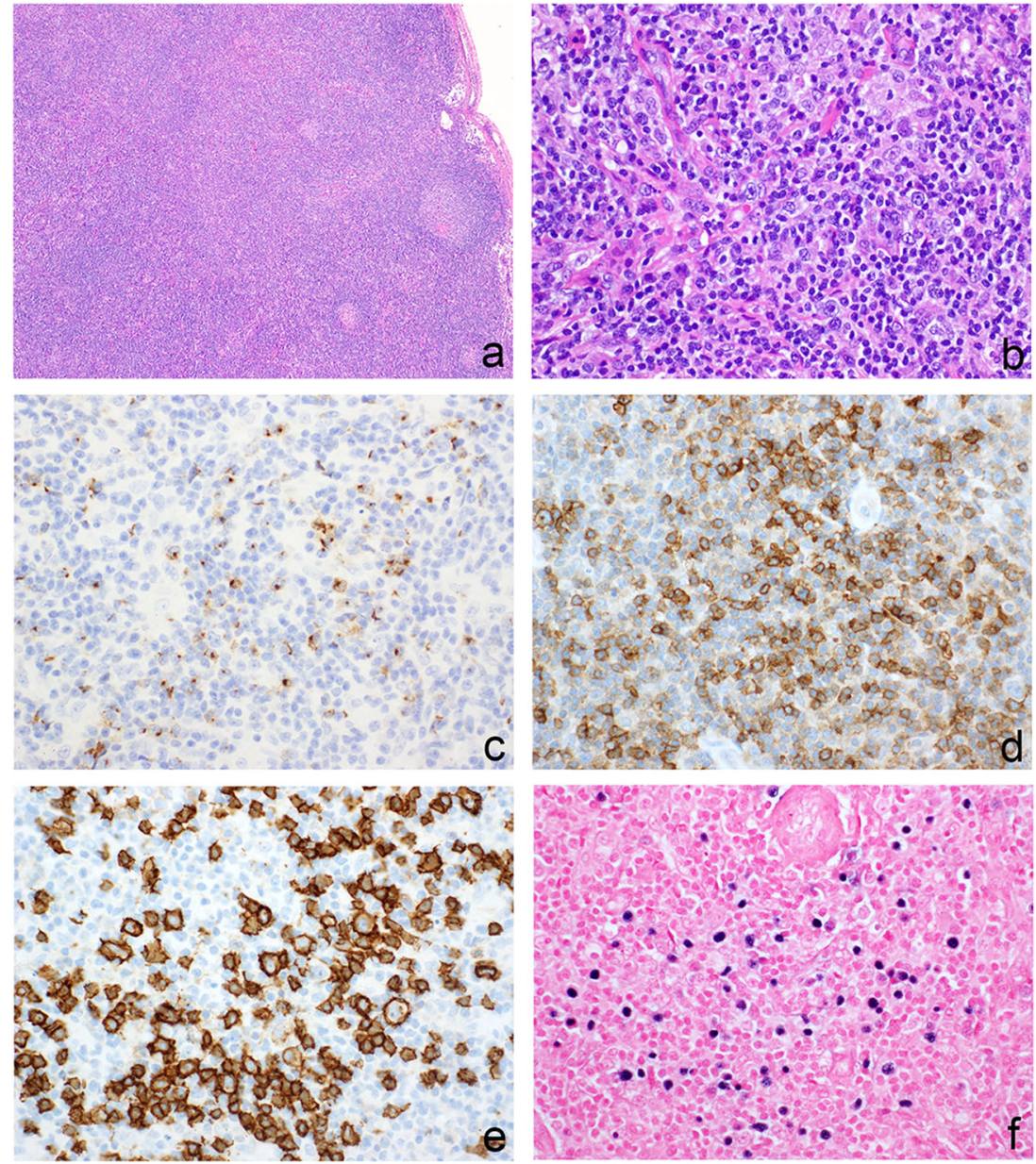

reactive $\mathrm{T}$ cells are also present in the background. CD21 and CD35 highlight follicular dendritic cell meshworks that are irregularly shaped and ramified. CD20 (Fig. 2e) and PAX-5 highlight scattered and small aggregates of $\mathrm{B}$ immunoblasts that are positive for $\mathrm{CD} 30$ and $\mathrm{EBV}$ as demonstrated by in situ hybridization for Epstein-Barr virus-encoded RNA (EBER; Fig. 2f), and negative for CD15. The overall findings confirm the diagnosis of AITL. The staging bone marrow biopsy shows no morphologic or immunophenotypic evidence of lymphomatous involvement.

The left cerebellum biopsy performed on July 2012 at our institution revealed hemorrhagic and focally necrotic brain parenchyma with diffuse involvement by atypical large lymphoid cells with irregular nuclear contours, prominent nucleoli, and moderate to abundant amount of cytoplasm (Fig. 3a, b). Immunohistochemical studies demonstrate that the atypical large cells are B cells that are positive for CD20 (Fig. 3c), CD79a, MUM-1, and CD30 (variable intensity), as well as EBV as demonstrated by EBER (Fig. 3d). There is a background infiltrate of small T cells with no apparent loss of pan$\mathrm{T}$ cell antigens or $\mathrm{CD} 4 / \mathrm{CD} 8$ subset restriction. The T cells are negative for CD10. Based on these findings, the diagnosis of DLBCL was rendered.
Molecular analysis was performed using formalin-fixed, paraffin-embedded tissue from the cervical lymph node and cerebellum biopsy specimens to assess the immunoglobulin heavy chain (IgH) gene, and T cell receptor (TCR) gamma and beta chain genes by polymerase chain reaction (PCR) in the presence of fluorescently labeled primers using methods described previously [23]. These studies showed presence of clonal TCR beta and TCR gamma gene rearrangements, with TCR gamma being biallelic/biclonal, but no evidence of clonal IgH gene rearrangement in the cervical lymph node specimen. On the other hand, clonal IgH gene rearrangement, but no evidence of clonal TCR gamma gene rearrangement, was demonstrated in the cerebellum biopsy specimen. An incomplete (D-J) TCR beta gene rearrangement was detected but clonally unrelated to the previously detected $\mathrm{T}$ cell clone.

\section{Discussion}

Expansion of EBV-infected large B cells is documented in up to $97 \%$ of AITL cases and is thought to reflect underlying immune dysfunction that is characteristic of AITL [12]. Although clonal immunoglobulin gene rearrangement can be 
Fig. 3 Diffuse large B cell lymphoma in the cerebellum. a Hemorrhagic and focally necrotic brain parenchyma with diffuse involvement by an atypical lymphoid proliferation $(\mathrm{H} \& \mathrm{E}$, $\times 100$ ), composed of $\mathbf{b}$ large lymphoid cells with irregular nuclear contours, prominent nucleoli, and moderate to abundant amount of cytoplasm (H\&E, $\times 400)$. $\mathbf{c}$ The atypical large cells are strongly positive for $\mathrm{B}$ cell marker CD20 (×400). d In addition, they are infected by EBV as demonstrated by their strong nuclear signals for in situ hybridization for EBV-encoded RNA $(\times 200)$
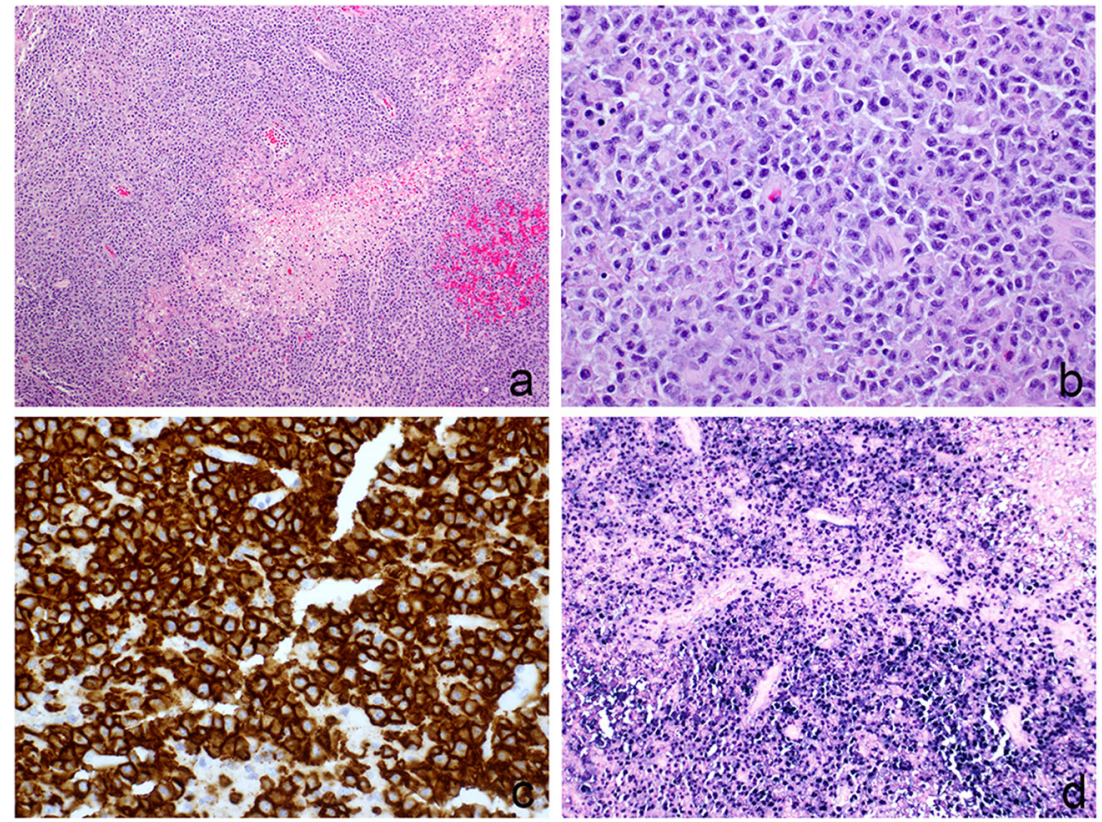

found in as many as $20-30 \%$ of AITL cases [5, 12], the expanded B cell component is generally polytypic and regarded reactive in nature, while subsequent development of EBV-associated B cell lymphomas in patients with AITL is rare. To our knowledge, only 21 cases of AITL with histologic progression to EBV-associated B cell lymphoma, involving nodal (13/21) and extranodal (8/21) sites, have been described in English literature [14-22, 24]. Reported extranodal sites of involvement include skin (three cases) [18-20], bone marrow (two cases) [14, 15], ileum (one case) [21], soft tissue (one case)[24], and lung (one case) [22]. The present case is the first report of CNS involvement as extranodal manifestation of EBV-associated B cell lymphoma following a diagnosis of AITL.

Including the present case, DLBCL is by far the most common subtype of EBV-positive B cell lymphoma occurring in patients with AITL (17/22; Table 1), including the case reported as "large-cell immunoblastic lymphoma of B cell immunophenotype" by Abruzzi et al., which based on the described morphologic features is most in keeping with DLBCL using 2008 WHO classification scheme. The remaining subtypes include four cases of classical Hodgkin lymphoma $[14,15]$ and one case of plasmacytoma [24]. The time interval between AITL and progression to B cell lymphoma ranged from 4 to 96 months. Simultaneous involvement by B cell lymphoma and AITL in the same anatomical site (composite AITL/B cell lymphoma) on initial presentation has also been reported [14, 15, 25, 26].

The pathogenesis of progression of AITL into DLBCL has not been fully elucidated. In a hypothetical model proposed by Dunleavy et al., EBV-infected B cells, by presenting EBV viral proteins to $\mathrm{T}$ cells through MHC class II molecules, provide stimulatory signals for $\mathrm{T}_{\mathrm{FH}}$ cell activation and CXCL13 production. CXCL13 might in turn stimulate further B cell activation, creating a co-stimulatory loop [13]. This complex interaction between EBV-infected B cells, T cells, and cytokines in AITL provides a possible pathogenetic mechanism for uncontrolled B cell proliferation and histologic progression to DLBCL.

Lymphoma-associated immune dysfunction also plays a pivotal role. Lymphomas arising in immunocompromised patients are frequently EBV-associated. As patients with AITL are prone to immunodeficiency, they are susceptible to either a primary or reactivated EBV infection. Since EBV preferentially infects $\mathrm{B}$ cells and possesses the unique ability to transform resting B cells into permanent, latently infected lymphoblastoid cell lines [27], it is highly conceivable that the virus plays a direct role in B cell lymphomagenesis in AITL.

Administration of systemic chemotherapy and/or T cell immunosuppressive agents represents another possible pathogenetic mechanism of EBV-associated B cell lymphoma occurring in patients with AITL [22]. These treatment protocols may further impair cellular immunity and promote uncontrolled proliferation of latently EBV-infected B cells. Our patient was on prednisone for approximately 3 months before developing DLBCL. Thus, lymphoma- and therapyassociated immunosuppression, as well as his advanced age, likely contributed to the high-grade histologic progression to DLBCL. Of interest, simultaneous infection by both EBV and HHV-6, which our patient also had, has been demonstrated to be associated with histologic progression in AITL cases [28].

While it is plausible to assume that EBV-positive B cell lymphoma is derived from the expanded EBV-positive B immunoblasts present in the background of AITL, no definitive 
Table 1 Clinicopathologic features and B/T cell clonality status of EBV-positive B cell lymphoma developing after the initial diagnosis of angioimmunoblastic $\mathrm{T}$ cell lymphoma

\begin{tabular}{|c|c|c|c|c|c|c|c|c|}
\hline Case No. & Authors (year) & Age/Sex & Tumor site & Diagnosis & $\begin{array}{l}\text { Time to } \\
\text { BCL Dx }\end{array}$ & $\begin{array}{l}\text { TCR gene } \\
\text { rearrangement }\end{array}$ & $\begin{array}{l}\text { IgH gene } \\
\text { rearrangement }\end{array}$ & EBER-ISH \\
\hline \multirow[t]{4}{*}{1} & \multirow[t]{4}{*}{ Attygalle AD (2007) [14] } & \multirow[t]{4}{*}{$28 / \mathrm{M}$} & $\mathrm{LN}$ & AITL & & N/Amp & N/Amp & ND \\
\hline & & & $\mathrm{LN}$ & AITL & & $\mathrm{R}$ & $\mathrm{NR}$ & ND \\
\hline & & & $\mathrm{BM}$ & AITL & & N/Amp & N/Amp & POS \\
\hline & & & $\mathrm{BM}$ & DLBCL & 24 & N/Amp & N/Amp & POS \\
\hline \multirow[t]{2}{*}{2} & \multirow[t]{2}{*}{ Attygalle AD (2007) [14] } & \multirow[t]{2}{*}{$60 / \mathrm{F}$} & LN & AITL & & $\mathrm{R}$ & NR & POS \\
\hline & & & $\mathrm{LN}$ & AITL and DLBCL & 8 & $\mathrm{R}$ & $\mathrm{R}$ & POS \\
\hline \multirow[t]{3}{*}{3} & \multirow[t]{3}{*}{ Attygalle AD (2007) [14] } & \multirow[t]{3}{*}{$59 / \mathrm{M}$} & $\mathrm{LN}$ & AITL & & $\mathrm{N} / \mathrm{A}$ & N/A & N/A \\
\hline & & & $\mathrm{LN}$ & DLBCL & 8 & $\mathrm{R}$ & $\mathrm{R}$ & POS \\
\hline & & & $\mathrm{LN}$ & AITL & a & Oligoclonal & NR & N/A \\
\hline \multirow[t]{2}{*}{4} & \multirow[t]{2}{*}{ Attygalle AD (2007) [14] } & \multirow[t]{2}{*}{$72 / \mathrm{M}$} & $\mathrm{LN}$ & AITL & & $\mathrm{R}$ & $\mathrm{R}^{\mathrm{b}}$ & N/A \\
\hline & & & $\mathrm{LN}$ & DLBCL & 84 & NR & $\mathrm{R}$ & POS \\
\hline \multirow[t]{2}{*}{5} & \multirow[t]{2}{*}{ Attygalle AD (2007) [14] } & \multirow[t]{2}{*}{$79 / \mathrm{F}$} & $\mathrm{LN}$ & AITL & & $\mathrm{R}$ & NR & POS \\
\hline & & & $\mathrm{LN}$ & $\mathrm{cHL}$ & 63 & NR & NR & POS \\
\hline \multirow[t]{2}{*}{6} & \multirow[t]{2}{*}{ Attygalle AD (2007) [14] } & \multirow[t]{2}{*}{$67 / F$} & $\mathrm{LN}$ & AITL & & $\mathrm{R}$ & N/A & POS \\
\hline & & & $\mathrm{LN}$ & $\mathrm{cHL}$ & 60 & NR & NR & POS \\
\hline \multirow[t]{2}{*}{7} & \multirow[t]{2}{*}{ Willenbrock K (2007) [15] } & $52 / \mathrm{F}$ & $\mathrm{LN}$ & AITL & & N/A & N/A & N/A \\
\hline & & & $\mathrm{LN}$ & DLBCL & 3 & NR & $\mathrm{R}$ & POS \\
\hline 8 & Willenbrock K (2007) [15] & $76 / \mathrm{F}$ & $\mathrm{LN}$ & AITL & & N/A & N/A & N/A \\
\hline & & & $\mathrm{LN}$ & DLBCL & 8 & N/A & N/A & POS \\
\hline 9 & Willenbrock K (2007) [15] & $46 / \mathrm{F}$ & $\mathrm{LN}$ & AITL & & N/A & N/A & N/A \\
\hline & & & BM & DLBCL & 5 & $\mathrm{R}$ & $\mathrm{R}$ & POS \\
\hline 10 & Willenbrock K (2007) [15] & $48 / \mathrm{M}$ & $\mathrm{LN}$ & AITL & & N/A & N/A & N/A \\
\hline & & & $\mathrm{LN}$ & $\mathrm{cHL}$ & 21 & $\mathrm{R}$ & NR & POS \\
\hline 11 & Willenbrock K (2007) [15] & $83 / \mathrm{F}$ & $\mathrm{LN}$ & AITL & & $\mathrm{N} / \mathrm{A}$ & N/A & N/A \\
\hline & & & $\mathrm{LN}$ & $\mathrm{cHL}$ & 31 & $\mathrm{R}$ & NR & POS \\
\hline 12 & Skugor ND (2010) [17] & $36 / \mathrm{F}$ & $\mathrm{LN}$ & AITL & & $\mathrm{N} / \mathrm{A}$ & N/A & N/A \\
\hline & & & $\mathrm{LN}$ & DLBCL & 13 & N/A & N/A & N/A \\
\hline 13 & Huang J (2011) [16] & $64 / \mathrm{M}$ & $\mathrm{LN}$ & AITL & & $\mathrm{R}$ & NR & POS \\
\hline & & & $\mathrm{LN}$ & DLBCL & 48 & NR & $\mathrm{R}$ & POS \\
\hline 14 & Abruzzo LV (1993) [18] & $46 / \mathrm{M}$ & $\mathrm{LN}$ & AITL & & NR & N/A & NEG \\
\hline & & & Skin & BCL-IB & 23 & N/A & N/A & N/A \\
\hline & & & $\mathrm{LN}$ & BCl-IB & 24 & NR & Oligoclonal & POS \\
\hline 15 & Hawley RC (2006) [19] & $69 / \mathrm{F}$ & $\mathrm{LN}$ & AITL & & $\mathrm{R}$ & NR & NEG \\
\hline & & & Skin & DLBCL & 56 & NR & $\mathrm{R}$ & POS \\
\hline 16 & Yang Q (2012) [20] & $65 / \mathrm{M}$ & $\mathrm{LN}$ & AITL & & N/A & N/A & POS \\
\hline & & & Skin & DLBCL & 19 & N/A & N/A & POS \\
\hline 17 & Weisel KC (2008) [22] & $59 / \mathrm{M}$ & $\mathrm{LN}$ & AITL & & N/A & N/A & POS \\
\hline & & & Lung & DLBCL & 11 & N/A & N/A & POS \\
\hline 18 & Takahashi T (2010) [21] & $66 / \mathrm{F}$ & LN & AITL & & $\mathrm{R}$ & NR & NEG \\
\hline & & & Ileum & DLBCL & 24 & NR & $\mathrm{R}$ & POS \\
\hline 19 & Zettl A (2002) [24] & $68 / \mathrm{M}$ & $\mathrm{LN}$ & AITL & & N/A & N/A & N/A \\
\hline & & & Soft Tissue & DLBCL & 34 & NR & $\mathrm{R}$ & POS \\
\hline 20 & Zettl A (2002) [24] & $47 / \mathrm{M}$ & $\mathrm{LN}$ & AITL & & $\mathrm{R}$ & NR & POS \\
\hline & & & $\mathrm{LN}$ & DLBCL & 29 & NR & Oligoclonal & POS \\
\hline 21 & Zettl A (2002) [24] & $61 / \mathrm{M}$ & $\mathrm{LN}$ & AITL & & R (biclonal) & NR & POS \\
\hline & & & $\mathrm{LN}$ & Plasmacytoma & 96 & $\mathrm{R}$ & Oligoclonal & POS \\
\hline 22 & Present case & $80 / \mathrm{M}$ & $\mathrm{LN}$ & AITL & & R (biclonal) & NR & POS \\
\hline & & & Cerebellum & DLBCL & 4 & Incomplete (D-J) & $\mathrm{R}$ & POS \\
\hline
\end{tabular}

$M$ male, $F$ female, $L N$ lymph node, $B M$ bone marrow, $D x$ diagnosis, $A I T L$ angioimmunoblastic T cell lymphoma, $D L B C L$ diffuse large B cell lymphoma, $c H L$ classical Hodgkin lymphoma, $B C L-I B$ B cell lymphoma large-cell immunoblastic, $R$ rearranged, $N R$ not rearranged, $N / A m p$ not amplifiable, $N / A$ not available, $P O S$ positive, $N E G$ negative

${ }^{a} 15$ months after the initial diagnosis of AITL and 7 months after the diagnosis of DLBCL

${ }^{\mathrm{b}}$ Weak; differential size from that detected in subsequent DLBCL 
clonal relationship between the two has been established in the published cases. Of the 21 reported cases (Table 1), IgH and TCR gene rearrangement studies with successful results for both AITL and DLBCL specimens were available in 11 cases, of which only one case (case 4) demonstrated presence of clonal IgH rearrangement in both DLBCL and AITL specimens. However, in this case, the monoclonal band detected in AITL was weak and differed in size to that of the subsequent biopsy with DLBCL. Similar to our case, four cases (cases 13, 15, 18, and 20) showed rearranged TCR/non-rearranged IgH genes in AITL, and rearranged IgH/non-rearranged TCR in DLBCL. Of the 11 DLBCL specimens with successful PCR, only 3 showed monoclonal TCR gene rearrangement, with only 1 of these 3 cases having morphologic evidence of synchronous AITL (case 2) [14]. TCR gene rearrangement was detected in three of five cases involved by other subtypes of B cell lymphoma (two cHL, one plasmacytoma). These observations suggest that AITL infrequently occurs synchronously with DLBCL upon histologic progression.

In these reported cases as well as our case, PCR analysis was undertaken utilizing whole tissue sections. In our case, and likely in other reported cases as well, the relative paucity of EBV-positive B immunoblasts compared to neoplastic T cells in the AITL specimen likely contributed to the decreased diagnostic sensitivity of IgH rearrangement assay utilizing whole tissue sections, and our inability to prove clonal relationship between the EBV-positive B immunoblasts in AITL and the DLBCL. PCR analysis using single-cell microdissection of the EBV-positive B immunoblasts was not possible in our case as the initial AITL biopsy was performed at another institution and worked up at two institutions, and additional tissue sections were not available. However, even if clonality analysis with single-cell microdissection was undertaken, the EBV-positive $\mathrm{B}$ immunoblasts may not necessarily exhibit clonal IgH gene rearrangement. In a study published by Bräuninger et al., PCR analysis of EBV-infected B cells microdissected from six cases of AITL ranged from small polyclonal to large monoclonal expansions, with frequent ongoing somatic hypermutation and acquisition of destructive mutation in IgH framework regions [29]. As the EBV-positive B immunoblasts were relatively few in number $(<10 \%)$ without forming cohesive sheets in our case, they may have been polyclonal or oligoclonal from the onset but rapidly underwent expansion and outgrowth of a dominant clone due to genomic instability, possibly exacerbated by HHV6 infection, leading to progression to EBV-positive B cell lymphoma.

To our knowledge, our case is the first report of EBVassociated DLBCL with CNS presentation following a diagnosis of AITL. We believe that this unique case expands the clinical spectrum of EBV-associated DLBCL complicating nodal AITL, and illustrates the importance of awareness of this diagnostic differential when confronted with a clinically atypical CNS lesion in a patient with known AITL.
Conflict of interest The authors declare that they have no conflict of interest.

\section{References}

1. Rudiger T, Weisenburger DD, Anderson JR, Armitage JO, Diebold J, MacLennan KA, Nathwani BN, Ullrich F, Muller-Hermelink HK (2002) Non-Hodgkin's Lymphoma Classification Project: Peripheral T-cell lymphoma (excluding anaplastic large-cell lymphoma): results from the Non-Hodgkin's Lymphoma Classification Project. Ann Oncol 13(1):140-149

2. Frizzera G, Moran EM, Rappaport H (1975) Angio-immunoblastic lymphadenopathy. Diagnosis and clinical course. Am J Med 59(6): 803-818

3. Frizzera G, Moran EM, Rappaport H (1974) Angio-immunoblastic lymphadenopathy with dysproteinaemia. Lancet 1(7866):1070-1073

4. Weiss LM, Strickler JG, Dorfman RF, Horning SJ, Warnke RA, Sklar J (1986) Clonal T-cell populations in angioimmunoblastic lymphadenopathy and angioimmunoblastic lymphadenopathy-like lymphoma. Am J Pathol 122(3):392-397

5. Tan BT, Warnke RA, Arber DA (2006) The frequency of B- and Tcell gene rearrangements and epstein-barr virus in T-cell lymphomas: a comparison between angioimmunoblastic T-cell lymphoma and peripheral T-cell lymphoma, unspecified with and without associated B-cell proliferations. J Mol Diagn 8(4):466-475

6. Jaffe ES (ed) (2008) World Health Organization: WHO classification of tumours: pathology and genetics of tumors of haematopoietic and lymphoid tissues. IARC, Lyon

7. Lopez-Guillermo A, Cid J, Salar A, Lopez A, Montalban C, Castrillo JM, Gonzalez M, Ribera JM, Brunet S, Garcia-Conde J, Fernandez de Sevilla A, Bosch F, Montserrat E (1998) Peripheral T-cell lymphomas: initial features, natural history, and prognostic factors in a series of 174 patients diagnosed according to the R.E.A.L. Classification. Ann Oncol 9(8):849-855

8. Pangalis GA, Moran EM, Nathwani BN, Zelman RJ, Kim H, Rappaport H (1983) Angioimmunoblastic lymphadenopathy. Longterm follow-up study. Cancer 52(2):318-321

9. Attygalle AD, Diss TC, Munson P, Isaacson PG, Du MQ, Dogan A (2004) CD10 expression in extranodal dissemination of angioimmunoblastic T-cell lymphoma. Am J Surg Pathol 28(1):54-61

10. Dorfman DM, Brown JA, Shahsafaei A, Freeman GJ (2006) Programmed death-1 (PD-1) is a marker of germinal centerassociated T cells and angioimmunoblastic T-cell lymphoma. Am J Surg Pathol 30(7):802-810

11. Grogg KL, Attygalle AD, Macon WR, Remstein ED, Kurtin PJ, Dogan A (2006) Expression of CXCL13, a chemokine highly upregulated in germinal center T-helper cells, distinguishes angioimmunoblastic T-cell lymphoma from peripheral T-cell lymphoma, unspecified. Mod Pathol 19(8):1101-1107

12. Anagnostopoulos I, Hummel M, Finn T, Tiemann M, Korbjuhn P, Dimmler C, Gatter K, Dallenbach F, Parwaresch MR, Stein H (1992) Heterogeneous Epstein-Barr virus infection patterns in peripheral Tcell lymphoma of angioimmunoblastic lymphadenopathy type. Blood 80(7):1804-1812

13. Dunleavy K, Wilson WH, Jaffe ES (2007) Angioimmunoblastic T cell lymphoma: pathobiological insights and clinical implications. Curr Opin Hematol 14(4):348-353

14. Attygalle AD, Kyriakou C, Dupuis J, Grogg KL, Diss TC, Wotherspoon AC, Chuang SS, Cabecadas J, Isaacson PG, Du MQ, Gaulard P, Dogan A (2007) Histologic evolution of angioimmunoblastic T-cell lymphoma in consecutive biopsies: clinical correlation and insights into natural history and disease progression. Am J Surg Pathol 31(7):1077-1088 
15. Willenbrock K, Brauninger A, Hansmann ML (2007) Frequent occurrence of B-cell lymphomas in angioimmunoblastic T-cell lymphoma and proliferation of Epstein-Barr virus-infected cells in early cases. Br J Haematol 138(6):733-739

16. Huang J, Zhang PH, Gao YH, Qiu LG (2012) Sequential development of diffuse large B-cell lymphoma in a patient with angioimmunoblastic T-cell lymphoma. Diagn Cytopathol 40(4): 346-351

17. Skugor ND, Peric Z, Vrhovac R, Radic-Kristo D, Kardum-Skelin I, Jaksic B (2010) Diffuse large B-cell lymphoma in patient after treatment of angioimmunoblastic T-cell lymphoma. Coll Antropol 34(1): 241-245

18. Abruzzo LV, Schmidt K, Weiss LM, Jaffe ES, Medeiros LJ, Sander CA, Raffeld M (1993) B-cell lymphoma after angioimmunoblastic lymphadenopathy: a case with oligoclonal gene rearrangements associated with Epstein-Barr virus. Blood 82(1):241-246

19. Hawley RC, Cankovic M, Zarbo RJ (2006) Angioimmunoblastic Tcell lymphoma with supervening Epstein-Barr virus-associated large B-cell lymphoma. Arch Pathol Lab Med 130(11):1707-1711

20. Yang QX, Pei XJ, Tian XY, Li Y, Li Z (2012) Secondary cutaneous Epstein-Barr virus-associated diffuse large B-cell lymphoma in a patient with angioimmunoblastic T-cell lymphoma: a case report and review of literature. Diagn Pathol 7:7-1596-7-7

21. Takahashi T, Maruyama R, Mishima S, Inoue M, Kawakami K, Onishi C, Miyake T, Tanaka J, Nabika T, Ishikura H (2010) Small bowel perforation caused by Epstein-Barr virus-associated B cell lymphoma in a patient with angioimmunoblastic T-cell lymphoma. J Clin Exp Hematop 50(1):59-63

22. Weisel KC, Weidmann E, Anagnostopoulos I, Kanz L, Pezzutto A, Subklewe M (2008) Epstein-Barr virus-associated B-cell lymphoma secondary to FCD-C therapy in patients with peripheral T-cell lymphoma. Int J Hematol 88(4):434-440

23. Nayak L, Hedvat C, Rosenblum MK, Abrey LE, DeAngelis LM (2011) Late relapse in primary central nervous system lymphoma: clonal persistence. Neuro Oncol 13(5):525-529

24. Zettl A, Lee SS, Rudiger T, Starostik P, Marino M, Kirchner T, Ott M, Muller-Hermelink HK, Ott G (2002) Epstein-Barr virus-associated B-cell lymphoproliferative disorders in angloimmunoblastic T-cell lymphoma and peripheral T-cell lymphoma, unspecified. Am J Clin Pathol 117(3):368-379

25. Xu Y, McKenna RW, Hoang MP, Collins RH, Kroft SH (2002) Composite angioimmunoblastic T-cell lymphoma and diffuse large B-cell lymphoma: a case report and review of the literature. Am J Clin Pathol 118(6):848-854

26. Tabata R, Tabata C, Yasumizu R, Kojima M (2014) Independent growth of diffuse large $\mathrm{B}$ cell lymphoma and angioimmunoblastic $\mathrm{T}$ cell lymphoma originating from composite lymphoma. Ann Hematol 93(10):1801-1803

27. Young LS, Rickinson AB (2004) Epstein-Barr virus: 40 years on. Nat Rev Cancer 4(10):757-768

28. Zhou Y, Attygalle AD, Chuang SS, Diss T, Ye H, Liu H, Hamoudi RA, Munson P, Bacon CM, Dogan A, Du MQ (2007) Angioimmunoblastic T-cell lymphoma: histological progression associates with EBV and HHV6B viral load. Br J Haematol 138(1):44 53

29. Brauninger A, Spieker T, Willenbrock K, Gaulard P, Wacker HH, Rajewsky K, Hansmann ML, Kuppers R (2001) Survival and clonal expansion of mutating "forbidden" (immunoglobulin receptordeficient) epstein-barr virus-infected b cells in angioimmunoblastic t cell lymphoma. J Exp Med 194(7):927-940 